\title{
Joseph Rogers and the reform of workhouse medicine
}

\author{
Ruth Richardson, Brian Hurwitz
}

This year is the centenary of the death of Joseph Rogers. No disease or anatomical discovery owes its eponym to him, yet he deserves to be known to readers of the $B M \mathcal{F}$ as well as Thomas Hodgkin or Sir Percival Pott.

Born to a Hampshire medical family in 1820 , Rogers dispensed for his father and was then apprenticed to a general practitioner in London. He was subsequently a star pupil at the Middlesex Hospital. By the age of 22 he had qualified as both apothecary and surgeon. ${ }^{1-4}$

\section{The dead and the living}

Rogers set up practice in Dean Street, Soho, a neighbourhood of mixed trades and fortunes. While caring for a patient with blood poisoning he noticed that the patient's living room wall "was exuding a highly putrid fluid." Rogers discovered that it formed part of the churchyard wall of St Anne's, Soho. He became active in burial reform and helped found the Anti-Interment-in-Towns Association, which succeeded in "thoroughly arousing the public mind to the revolting details of burials in London." The agitation prompted Lord Palmerston to close some of the worst metropolitan burial grounds, among them that of St Anne's. ${ }^{15-8}$

In 1854 under new legislation, the vestry appointed Rogers to the first Burial Board in London to acquire and supervise a suburban burial ground for parishioners. It took him three or four years of "incessant effort and pleading" to establish the first public mortuary in London, opened in St Anne's parish in 1856. It long remained the solitary instance of such provision..$^{16910}$

Rogers also campaigned against the window tax, then levied at a rate of eight shillings for each window. He knew that the effects of blocked windows in poor people's homes, where light and air was scarce, intensified disease and rendered recovery more difficult. Condemned as "a tax on health, cleanliness, and architectural propriety," the tax was finally removed in 1851 , just in time for the erection of the Crystal Palace. ${ }^{111} 12$

Calamity struck in 1854-5, when a cholera epidemic left Soho with an unhealthy reputation. Many paying patients had died or moved away, and Rogers's opportunity to earn a living had all but evaporated. In 1856, he became medical officer at the local workhouse. Modernised and internally redesigned, the buitding is now the outpatient department of the Middlesex Hospital. Had Rogers not recorded his experiences few familiar with Cleveland Street today could possibly imagine what scenes of real misery passed within those walls. ${ }^{13}$

1 Ashby Grove, London N1 3PR

Brian Hurwitz, MRCGP, general practitioner

Correspondence to: $\mathrm{Dr}$ Richardson.

\section{The deterrent workhouse}

The portal of the Strand Union Workhouse on Cleveland Street exhibited the only decorative feature of the entire building; a stone relief of an old man pointing to a stone drapery inscribed with the motto:

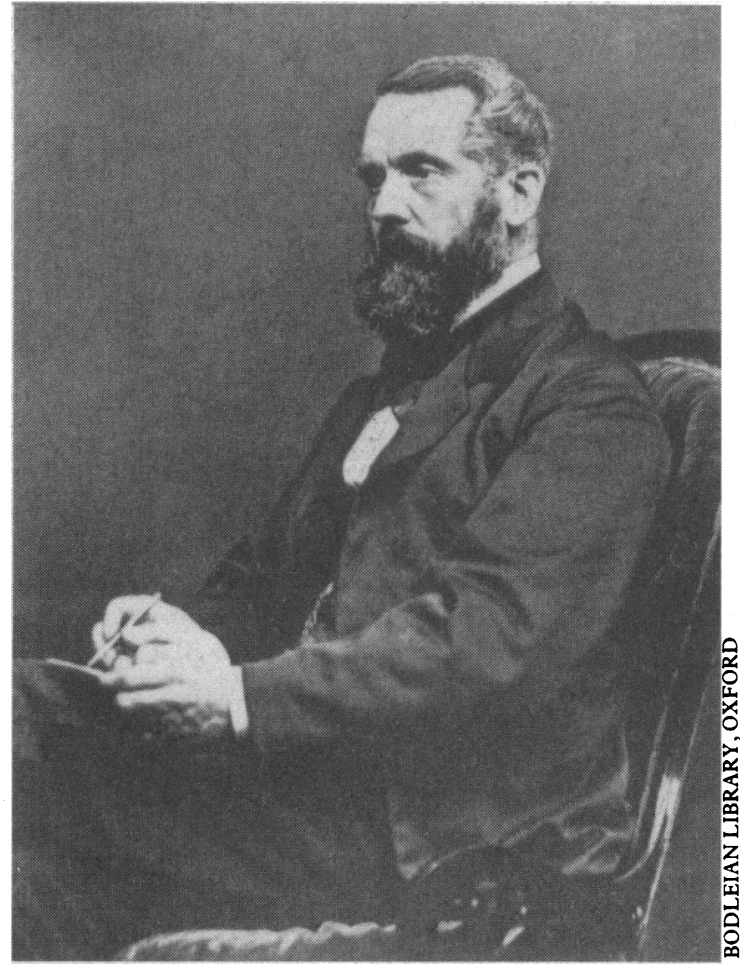

Dr foseph Rogers

"Avoid idleness and intemperance." The inscription captures perfectly the judgmental attitude towards poverty that was so characteristic in the Victorian workhouse regime. ${ }^{14}$

Workhouses were established under the 1834 New Poor I aw to curtail public spending on poverty. They were built by unions of parishes, and their management was overseen by local guardians of the poor. In Rogers's time the workhouse system was the largest civil organisation in the country, having 700 institutions. To receive assistance poor people had to live in the workhouse, which entailed the sale of personal belongings, the break up of homes, and the separation of families. Called "bastiles" by the poor, they effectively imprisoned the sick, the unemployed, the disabled, the insane, and the elderly. ${ }^{15-17}$

Rogers described the Strand Workhouse as:

a square four-storied building, with wings at each corner. The laundry of the establishment, which never in my time fell below five hundred inmates, was in the cellar [and] filled the house with steam and the odours [of] paupers' linen. Across the yard was a lean-to building, with windows in the front only, used as a day and night ward for infirm women. A tinker's shop with a forge and unceiled roof communicated with a ward for fever and foul cases. At the back there was a carpenter's shop and a dead house.

Few Victorian workhouses had separate infirmary buildings. The Strand Workhouse was no exception. Only two of its 20 wards were designated for the sick. But because illness and old age were the primary causes 


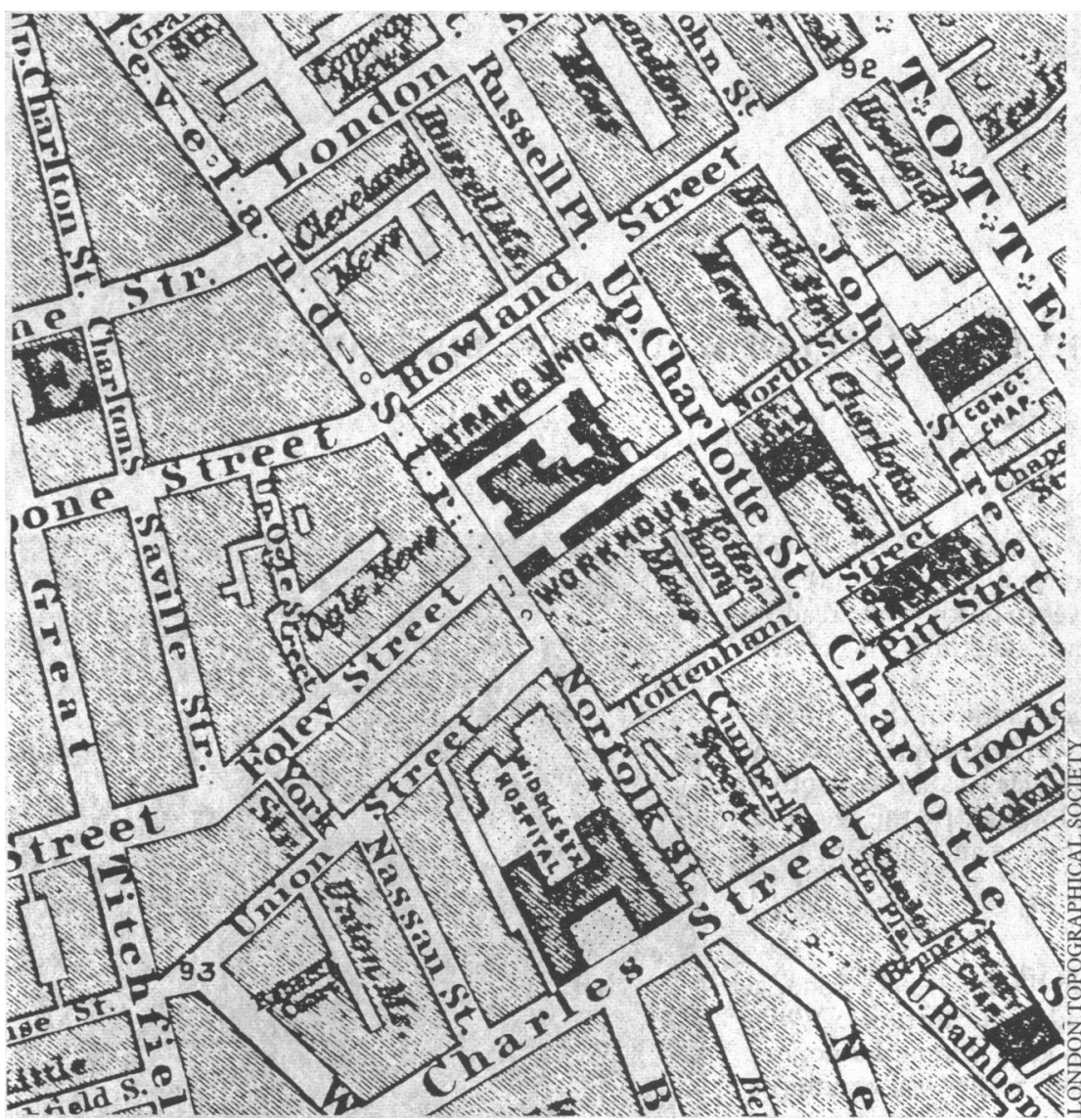

Map showing Strand Union Workhouse and Middlesex Hospital in 1862

of poverty Rogers found himself caring for sick and dying patients throughout the building. Only eight per cent of inmates were well. ${ }^{16} 18$

Rogers found unmarried mothers in the workhouse nursery (postnatal) ward suffering from extreme exhaustion. The practice in the lying-in ward, over which he had no jurisdiction, was to keep unmarried mothers on a starvation diet for nine days after confinement. He sought permission from the Poor Law Board at Whitehall to introduce a more humane diet, and was informed that the workhouse doctor could specify the diet for lying-in patients, "a power which," Rogers said, "I did not hesitate to use." Enraged by the direct approach to Whitehall, the Strand guardians censured Rogers. The "starvation dietary for single parturient women" had been established by the guardians themselves as "a deterrent against the use of the workhouse as a place in which to be confined. ${ }^{119}$

\section{Conflicts of interest}

Rogers's “wretched stipend" amounted to only $£ 50$ a year, from which all medicines were to be provided. $\mathrm{He}$ later wrote: "The sick of the Strand Union got very little in the way of medicine before I was appointed, and the provision of such medicines was to me in every sense a pecuniary loss." He was later to call for the abolition of this method of financing prescribing in evidence to a parliamentary select committee. ${ }^{11}$

A recurring problem of workhouse medicine was the impossibility of segregating patients with terminal, acute, chronic, and infectious diseases. Having no casualty provision, no trained nursing staff, few drugs, and no surgical facilities, workhouses could not adequately cope with acute cases. Some metropolitan guardians paid subscriptions to charitable hospitals for the care of their acutely ill. To contain costs, however, the Strand guardians kept a tight rein on Rogers's referrals. He once gained permission to send a few patients to a charity hospital but was accused of trying to save himself trouble. Some guardians pressed for the cab fares to be deducted from his salary. ${ }^{13} 19-22$

"Able bodied" poor earned the guardians $£ 400$ a year by beating carpets in the workhouse yard.

Despite the noise and dust, the Guardians persisted in carrying it on for ten of the twelve years I was there. The noise was so great that it effectually deprived the sick of all chance of sleep, whilst the dust was so thick that to open the windows was entirely out of the question.

Rogers tried repeatedly to stop this noxious method of generating revenue, but the guardians' fierce hostility forced him to abandon the idea. ${ }^{161819}$ Nevertheless, Rogers had some successes. At his own expense he established a workhouse dispensary, and he got the laundry moved to a new building in the yard, making more space for wards. Though he did some teaching himself, he found melancholy the wastage of the "vast field of clinical observation" in large urban workhouse wards: "There are certain diseases which can hardly be seen anywhere else," he wrote. Conditions of overcrowding were sometimes so bad at the Strand that patients could only get out at the end of their beds. Rogers had to tackle epidemics of measles and fevers in which there were more deaths than recoveries. He had ceilings in the sick wards opened to the roofspace, but the "exceedingly defective" ventilation was little improved. Though individual provision in prisons and barracks was $25 \mathrm{~m}^{3}$ (900 cubic feet) and $34 \mathrm{~m}^{3}$ (1200 cubic feet), in the Strand Workhouse each bed had only $13 \mathrm{~m}^{3}$ (466 cubic feet). In the nursery ward this figure was halved. In 1866, 556 people were sharing 332 beds. ${ }^{1} 161819$

\section{Rough music and reform}

The Strand master and matron, $\mathrm{Mr}$ and Mrs Catch, had an "excellent understanding" with the chairman of the guardians. After an agreed absence in May 1857, when he sat his examination for MD at St Andrews, Rogers found himself assailed by accusations of neglect. Another conspiracy, designed to provoke dereliction of duty by Rogers, backfired, and Catch himself was

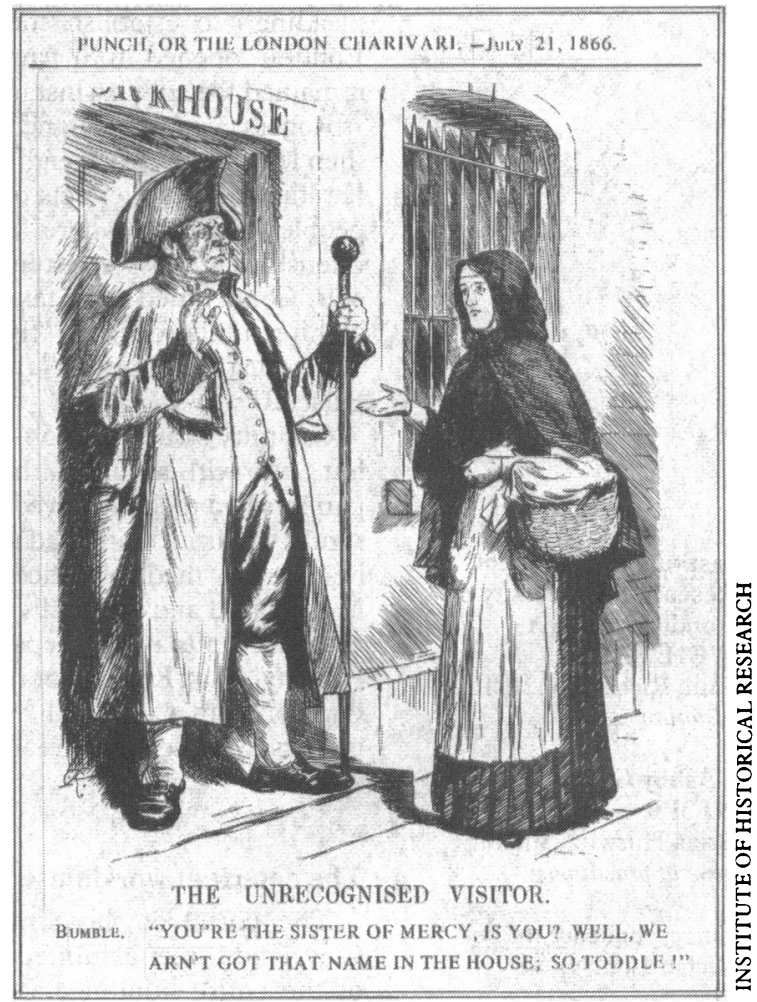

"Punch" cartoon depicting Bumbledom in 1866 


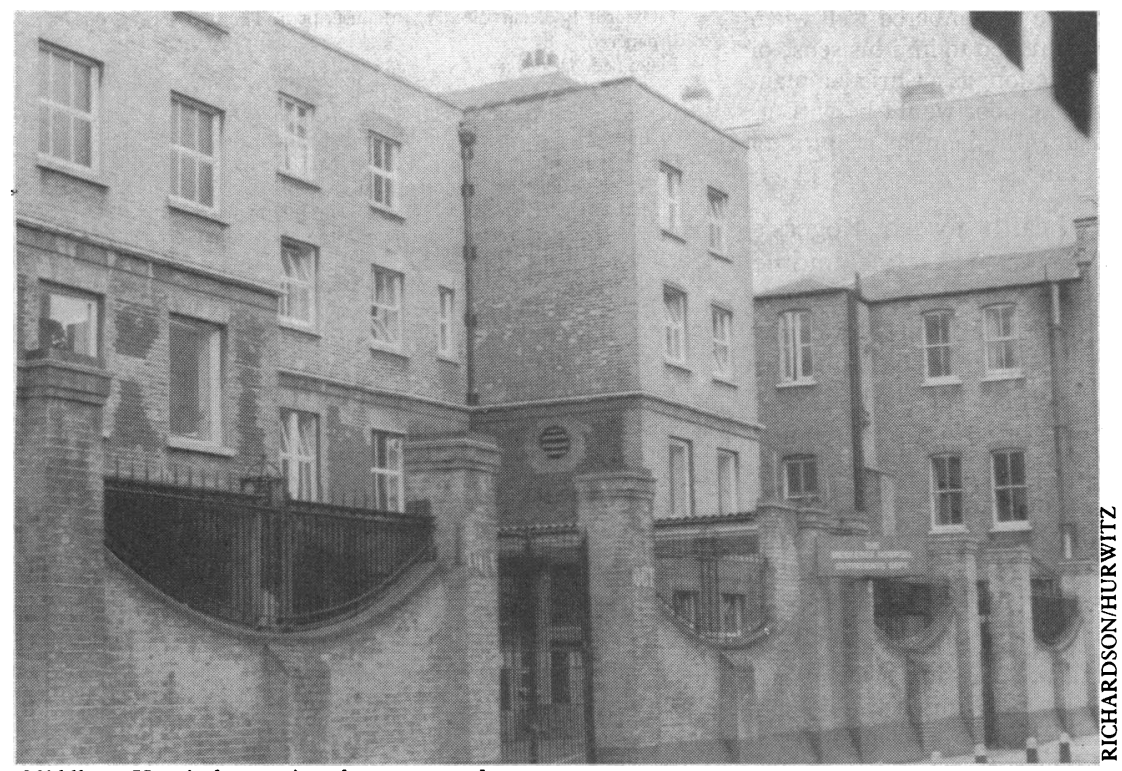

Middlesex Hospital outpatient department today

exposed. "So intensely tyrannical and cruel had been the rule of this man, that the day he resigned the keys, the whole establishment rose up in open rebellion, and with old kettles, shovels, penny trumpets, celebrated their departure from the premises." Catch later took his own life when, like $\mathrm{Mr}$ Bumble, the fictional workhouse master in Oliver Twist, he was faced with the prospect of having to enter the workhouse as a pauper himself. ${ }^{123}$

Throughout his time at the Strand workhouse Rogers was active in Poor Law medical reform. The Lancet approached him to advise on its importan investigation of the London workhouses in 1865. The late editor, Thomas Wakley, had declared workhouse wards to be "ANTE-CHAMBERS OF THE GRAVE." His sons published the Lancet Sanitary Commissioners' reports at intervals over $1865-6 .^{124} 25$

The State hospitals are in workhouse wards. They are closed against observation; they pay no heed to public opinion; they pay no toll to science. They contravene the rules of hygiene, they are under the government of men [masters and guardians] profoundly ignorant of hospital rules. The doctor and patient are alike the objects of a pinching parsimony. ${ }^{26}$

Soon after publication Rogers held a dinner party at his home in Dean Street, at which the Association for the Improvement of London Workhouse Infirmaries was founded. Its aims were to establish in London six Poor Law hospitals, each with 1000 beds, to reclassify and rehouse the workhouse population, and to group metropolitan Poor Law districts into one hospital region to bear the cost of the sick poor. Soon "names and money poured in on the scheme," and the association's committee boasted 20 MPs among its 70 members. ${ }^{12728}$

At its first meeting in 1866 Rogers, as secretary, read aloud a letter from Charles Dickens:

\section{My Dear Sir}

My knowledge of the general condition of the Sick Poor in workhouses is not of yesterday, nor are my efforts in my vocation to call merciful attention to it. (Cheers) Few anomalies in England are so horrible to me as the unchecked existence of many shameful sick wards for paupers, side by side with a constantly recurring expansion of conventiona wonder that the poor should creep into corners to die, rather than fester and rot in such infamous places. (Cheers) ${ }^{2 x}$

Critics of the workhouse system were vindicated when the government's official inquiry reported in 1866. The inspector admitted that most workhouses lacked light, ventilation, and space. Beds were too close together and there was insufficient sanitation, often with no privacy or toilet paper being provided. Guardians, he said, should provide all drugs, better food, and higher medical salaries. Finally, he recommended that several workhouses, including the Strand, be closed immediately..$^{16}$

In 1867 the outgoing president of the Poor Law Board, Gathorne Hardy, carried his Metropolitan Poor Act through Parliament, acknowledging his indebtedness to Joseph Rogers. Under the act London local authorities were to provide new infirmaries, separate from workhouses. A central health authority, the Metropolitan Asylums Board, was created to deal with infectious diseases and insanity. The next decade saw the construction of 20 new hospitals in the capital, totalling 10000 beds, with some professional nursing. One observer has commented: “Gathorne Hardy's Act proved to be the most important Poor Law measure for London between 1834 and 1929 and a significant step towards the socialisation of medical care in this country." Rogers's national campaigning prompted the adoption of similar schemes in several major towns, including Birmingham, Southampton, Plymouth, Oxford, and Cardiff. ${ }^{1624272931}$

\section{Common causes}

After requesting an official inquiry into a serious case of neglect by workhouse staff in 1868 Rogers was suspended from his post by the Strand guardians. Despite considerable local protest the guardians at last had their way. The Poor Law Board failed to support him, and Rogers was forced to resign. ${ }^{132}$

Although his former employers thought him "disposed of," Joseph Rogers proved quite as effective outside the workhouse as within. Over the next five years he established a powerful new pressure group, the Poor Law Medical Officers' Association. As president he drew attention "to the evils of inefficient provision for public medical relief" and showed convincingly that poor rates were lower "wherever medical relief to the poor was efficient." Rogers's efforts were also acknowledged as crucial to the passage of the Medical Officers' Superannuation Bill in 1870, before which no pension provision existed for doctors working in the public sector. ${ }^{162433-38}$

In 1872 Joseph Rogers returned to the Poor Law service as medical officer at the Westminster Infirmary in Poland Street. He was to remain there for 14 years. But once again he found his assessment of patients' needs in conflict with meagre provision. Again, he found himself liable to the abuses of petty officialdom and corruption. In 1883 he was suspended again, after giving evidence to an inquiry into the workhouse master's misconduct. But times had changed. Ratepayers and doctors rallied round him, a large testimonial fund was collected nationally, and parliamentary questions were asked. With the parish in ferment "the whole of the old gang of guardians were ejected from office by overwhelming majorities." The master was sacked, and Rogers's suspension overturned.'

The $B M 7$, for whom Rogers was a regular contributor on Poor Law matters, later observed:

Dr Rogers had turned over the stone of ancient abuse, and had shown to the world ... the vermin that throve in the darkness. As might have been expected, there was a mighty squirming and wriggling. ${ }^{739}$

\section{Child of the New Poor Law}

The following year Rogers and his wife Adriana were presented with a handsome testimonial at the Medical Society of London. Tributes were made to his humanity, kindness, and tenacity. Thanking all present, Rogers said he was himself 
a child of the New Poor Law ... he remembered well when the Bill became law, his father expressed to him his sense of deep disappointment and dissatisfaction, as a Christian man, with its harsh and bitter spirit. The poor would be with us always, and it was best to deal with them in a spirit of conciliation, moderation, and kindness.

Only two years later ill health forced Rogers's reluctant retirement from workhouse practice, and he moved to Hampstead for better air. There he died, in a house overlooking the recently built New End Hospital, a hundred years ago. Rogers had lived to see the old Strand workhouse rebuilt as part of the Middlesex Hospital and the new Strand Infirmary, now the North Middlesex Hospital, erected at Edmonton. In his will Rogers left funds to establish a prize for the best essay on the care of the sick poor. ${ }^{1} 190-1$

His obituary announced:

A prince has fallen out of our ranks. . . His life's work was a long series of reforms in sanitary law and administration, and in wringing from tardy Bumbledom justice for its ministers. ${ }^{\circ}$

Rogers's reminiscences were published posthumously. His brother Thorold observed in the preface that Joseph Rogers:

. had the good fortune to see that what he had laboured for and had been persecuted for, was now acknowledged to be humane, politic, and economical. He was met by obstacles which would have daunted a less resolute man; but he was sustained by the rectitude of his aims, and by a firm belief in their wisdom. Such men change the face of the world.

We thank staff at the manuscripts collection, Bodleian Library, Oxford; Nina Evans and other staff at the British Library, Bloomsbury; the British Library of Political and Economic Science; Stephen Goulder for access to the Middlesex Hospital archive; Dr M Rogers; the Royal College of Physicians; the Society of Apothecaries; Robin Smart, keeper of muniments, University of St Andrews; and the Wellcome Institute Library and Westminster Public Libraries.

1 Rogers JET, ed. Reminiscences of a workhouse medical officer. London: Fisher Unwin, 1889:xii-xxv;1-5;7-18;21-3;29-36;39-44;47-56;60;63;66-82;88-91; 93-103;111-201;211-40;246-52.

2 Joseph Rogers's certificates of medical qualifications and awards. Oxford: Bodleian Library. (Manuscripts in the Thorold Rogers collection of papers.) 3 Everitt T. Testimonial for Joseph Rogers. (Middlesex Hospital, London, 1840.)
Oxford: Bodleian Library, (Manuscript in Thorold Rogers collection of papers.)

+ Lee S, ed. D

1897:125-6.

6. Smith, Elder. (8)eral Register Office. HM Census Returns 1841-81, Marvlebone District. Entry for Dean Street. Marylebone Public Library.)

6 [? Hart E.] Obituary of Joseph Rogers, MD. Lancet 1889;i:764-6.

7 [? Hart E.] Obituary of Joseph Rogers, MD., chairman of the Poor Law Medical Officers' Association. Br Med f 1889:i : $864-7$.

8 Burial books for parish of St Anne, Westminster. (Manuscript in Westminster Public Libraries.)

9 Cardwell JH, Freeman HB, Wilton GC, et al. Two centuries of Soho. London: Truslove and Hanson, 1898:14,183-5.

10 Burial Board minutes for parish of St Anne, Westminster. (Manuscript in Westminster Public Libraries.

11 Gauldie E. Cruel habitations. London: Allen and Unwin, 1974:345.

12 Godwin $G$. The opening of a new volume. The Builder 1846:1.

13 Smith FB. The people's health 1830-1910. London: Croom Helm, 1979:388-9.

14 Anonymous. Sermons in stone. The Builder 1858:9:613.

15 Longmate N. The Workhouse. London: Croom Helm, 1974

16 Smith E. (Poor Law inspector and medical of ficer to Poor Law Board). Report on the metropolitan workhouse infirmaries and sick wards. British Parliamentary Papers 26 June 1866; LXI:372.

17 Baxter GRW. The book of the bastiles; or, the history of the working of the New Poor Law. London: John Stephens, 1841.

18 Cane RB. Report to the Poor Law Board ... into certain allegations made by Matilda Beeton in reference to the treatment of the sick in the Strand Union Workhouse. British Parliamentary Papers 25 June 1866;LXI:362.

19 Copies of letters concerning Dr Rogers and the Guardians of the Strand Union Workhouse. British Parliamentary Papers 10 August 1866;LXI:523.

20 Cobbe FP. The Workhouse as an hospital. London: Emily Faithfull, 1861 .

21 Twining L. State hospitals, or, nursing in workhouse infirmaries. London Women's Printing Society, 1888

22 Twining L. Workhouses and pauperism. London: Methuen, 1898

23 Dickens C. Oliver Twist; or, the parish boy's progress. London: 1837-9:chapter 53.

24 Hodgkinson R. The origins of the National Health Service. London: Wellcome, 1967:434.

25 Wakley T Mortality in Poor-Law workhouses Lancet 1840-1;ii: 194

26 The Lancet Sanitary Commission for Investigating the State of the Infirmaries of Workhouses. Report of the commissioners on metropolitan infirmaries. London: Lancet, 1861 :iv-v.

27 Ayers GM. England's first state hospitals, 1867-1930. London: Wellcome, 1971:8.

28 Association for the Improvement of London Workhouse Infirmaries . Report of a meeting, 3 March 1866. London: Savill and Edwards, 1866.

29 Abel-Smith B. A history of the nursing profession. London: Heinemann, 1960:36-49.

30 Williams K. From Sarah Gamp to Florence Nightingale. In: Davies C, ed. Rewriting nursing history. London: Croom Helm, 1980:41-75.

31 Abel-Smith B. The hospitals. London: Heinemann, 1964:66-82;152-72.

32 Correspondence relating to the resignation of Dr Rogers, from the Strand Union. British Parliamentary Papers 1867-8; XXI:93.

33 Brand JL. The parish doctor: England's Poor Law medical officers and medical reform, 1870-1900. Bull Hist Med 1961;ii:97-122.

34 Metropolitan and provincial Poor Law medical officers. Report of the aggregate meeting 24 fune 1868. London: Nicholls, 1868.

35 Rogers J. The Poor Law service. Br Med f 1870;ii:261.

35 Rogers J. The Poor Law service. Br Med f 1870;ii:261.

36 Rogers J. Poor Law medical reform. Br Med f 1870;ii:344.

38 Rogers J. The Poor Law Medical Officers Superannuation Bill. Br Med 7 Rogers $\mathrm{J}$. The
$1879 ; 1: 351-2$.

39 [? Hart E.] Dr Joseph Rogers. Br Med f 1889;i:847.

40 Anonymous. A new asylum for the sick poor. The Builder 1875:592.

41 Anonymous. The late Dr Joseph Rogers. Lancet 1889;ii:298.

\section{ANY QUESTIONS}

Narcotic drug addicts are often treated with reducing doses of methadone, but sweating is an unwelcome side effect. What treatment is advised to reduce this sweating?

As well as being a symptom of opiate withdrawal sweating is a well known side effect of methadone, occurring in up to half the cases when high doses are administered. ' Although unpleasant, it causes no medical problems or other symptoms even during vigorous exercise in high temperatures. Patients should be reassured that it will resolve with dose reduction; this may encourage them to continue the detoxification treatment. The condition rarely needs treatment, and this in itself may be a valuable learning experience for a patient who is accustomed to a pharmacological response to all symptoms. ${ }^{2}$ If medication is necessary to retain the patient in treatment or to prevent self medication with harmful alternatives a small dose of phenothiazine might be helpful. This class of drugs is unlikely to result in abuse or dependence, and their anticholinergic properties would be useful. Thioridazine ( $25 \mathrm{mg}$ once or twice daily) would be an appropriate choice as it is the most potent muscarinic antagonist of the group and would therefore suppress sweating most effectively. ${ }^{23}-\mathrm{A} \mathrm{H}$ GHODSE, professor of psychiatry, London

1 Kreek MJ. Medical management of methadone maintained patients. In: Lowinson JH, Ruiz P, eds. Substance abuse. Clinical problems and perspectives. Baltimore: Williams and Wilkins, 1981:660-73.

2 Ghodse AH. Drugs and addictive behaviour. A guide to treatment. Oxford: Blackwell Scientific, 1989.
3 Baldessarini RJ. Drugs and the treatment of psychiatric disorder. In: Goodman LS, Gilman A, eds. Goodman and Gilman's the pharmacological basis of therapeutics. New York: Macmillan, 1980:391-447.

How hazardous is an insect repellent containing bioallethrin and piperonyl butoxide?

These substances are often found together in proprietary aerosol insecticides of the fast acting ("knock down") type. Allethrin is the insecticide; piperonyl butoxide is a synergist that potentiates allethrin's toxicity by inhibiting catabolic microsomal enzymes. This permits the effective insecticide concentration to be reduced by up to $90 \%$. Allethrin is a synthetic pyrethrin, similar to naturally occurring insecticides. It may cause allergic dermatitis, rhinitis and asthma, chemical pneumonitis, and liver or kidney damage.' Sensitised individuals may show cross reactions with chrysanthemums and ragweed. Anaphylactic reactions have been reported, as have deaths after ingestion of large doses. All reports are, however, rare, and the compound is relatively harmless with normal use. Piperonyl butoxide is an experimental mutagen, but the limited data do not suggest that it is an animal or human carcinogen. ${ }^{3}-\mathrm{A}$ SCOTT, senior employment medical officer, Nottingham

1 Sax NI, Lewis JR Sen, eds. Dangerous properties of industrial materials. Vol II New York: Van Nostrand Reinhold, 1989:108.

2 Finkel AJ, ed. Insecticides. In: Hamilton and Hardy's industrial toxicology. th ed. London: John Wright PSG Inc. 1983:297.

3 Innes JRM. Ulland DM. Valerio MG. et al. Bioassay of pesticides and industrial chemicals for tumorigenicity in mice: a preliminary note. Fournal of The National Cancer Institute 1969;42:1101-4. 